\title{
Another paradigm lost? Autumn downstream migration of juvenile brown trout: Evidence for a presmolt migration
}

\author{
Aarestrup, Kim; Birnie-Gauvin, Kim; Larsen, Martin Hage
}

Published in:

Ecology of Freshwater Fish

Link to article, DOI:

10.1111/eff.12335

Publication date:

2018

Document Version

Publisher's PDF, also known as Version of record

Link back to DTU Orbit

Citation (APA):

Aarestrup, K., Birnie-Gauvin, K., \& Larsen, M. H. (2018). Another paradigm lost? Autumn downstream migration of juvenile brown trout: Evidence for a presmolt migration. Ecology of Freshwater Fish, 27(1), 513-516. https://doi.org/10.1111/eff.12335

\section{General rights}

Copyright and moral rights for the publications made accessible in the public portal are retained by the authors and/or other copyright owners and it is a condition of accessing publications that users recognise and abide by the legal requirements associated with these rights.

- Users may download and print one copy of any publication from the public portal for the purpose of private study or research.

- You may not further distribute the material or use it for any profit-making activity or commercial gain

- You may freely distribute the URL identifying the publication in the public portal 


\section{Another paradigm lost? Autumn downstream migration of juvenile brown trout: Evidence for a presmolt migration}

The salmonidae life cycle is generally described as beginning in inland freshwater streams or rivers, where young fish (or parr) will spend the first 1-3 years of their lives. Parr then undergo extensive physiological and morphological transformation-also known as smoltification-to prepare for life at sea (Aarestrup, Nielsen, \& Koed, 2002; Jonsson \& Jonsson, 1993; Klemetsen et al., 2003). Once in marine waters, salmonids undergo the majority of their somatic growth and return in freshwater to spawn, typically in late summer and autumn, after having spent 6 months to 3 years at sea (Davidsen et al., 2013).

While seaward migration of juvenile fish outside the peak spring period has been well documented in Atlantic salmon (Salmo salar; Cunjak, Chadwick, \& Shears, 1989; Jonsson \& Jonsson, 2014), few studies have published data to support an autumn outmigration in brown trout (Salmo trutta), despite the many observations of its occurrence (e.g., Winter, Tummers, Aarestrup, Baktoft, \& Lucas, 2016). In Atlantic salmon, this movement is considered a presmolt migration, perhaps as juveniles are entering estuaries, although they may not leave for sea until the following spring (Cunjak et al., 1989). For brown trout, it has been suggested that this movement is merely in-stream displacement or potadromous migration (Cucherousset, Ombredane, Charles, Marchand, \& Baglinière, 2005). The underlying causes of these movements are unclear, and may require us to rethink what we have considered the paradigm of salmonid biology (coined by Gowan, Young, Fausch, \& Riley, 1994). In this study, we aimed to characterise the length distribution and the sex of autumn-migrating trout in an attempt to better understand the underlying causes of autumn migration.

The River Lilleaa flows through agricultural land for approximately $35 \mathrm{~km}$ and is considered the most important sea trout tributary to River Gudenaa (K. Aarestrup, personal communication). A weir at Løjstrup Mill fish farm is situated two km upstream from the confluence with River Gudenaa, where a trap was erected to capture fish as they move downstream (Figure 1). Descending fish were caught in a wolf trap (8$\mathrm{mm}$ grid spacing), fully covering fish passage within the stream. The trap typically operated in full unless river flow exceeded $5 \mathrm{~m}^{3} \cdot \mathrm{s}^{-1}$. With larger flow, however, spill gates were open to allow excess water to exit the trap; thus, a portion of the fish were lost on days with elevated flow. The trap was running from 1 October to 29 October 2004 and was maintained daily. A subsample of migrating fish $(n=222)$ were measured for total length to the nearest $\pm 5 \mathrm{~mm}$ on 18 October. Of these fish, 84 trout were randomly chosen to be sexed (through dissection and genitalia identification). Data on water flow were obtained from a fixed data logger, located $100 \mathrm{~m}$ downstream of the trap.

We used a goodness-of-fit test to determine whether the sex ratio of migrating trout differed from 50:50 (male:female). A GLM (generalised linear model) was used to assess whether the average length differed between males and females (data passed normality test and homogeneity of variance). All statistical analyses were performed in $R$ version 3.0.1 (R Development Core Team 2013).

A total of 3,679 juvenile trout were caught between 1 October and 29 October 2004 (Figure 2). The start of capture coincided with the first major flow event. Unfortunately, the two major flow events (18 October and 22 October) necessitated the opening of the spill gates in order to release excess water, which enabled descending fish to escape capture. For this reason, we did not perform statistical analysis to investigate the effects of water flow on downstream migration, although the data suggest a strong association with water flow (Figure 2). The average length of the migrating trout was $14.3 \pm 2.7 \mathrm{~cm}$, ranging from 9.0 to $21.0 \mathrm{~cm}(n=222$, Figure 3). The sex ratio was $68 \%$ females to $32 \%$ males and differed significantly from an even distribution (goodness-of-fit test, $\chi^{2}=10.71, d f=1, p=0.001$, Figure 2). The average length did not differ between males and females (GLM, $F=0.003$, $d f=1, p=0.956$ ).

A considerable proportion of the River Lilleaa brown trout population undergoes autumn downstream migration. Our findings suggest that autumn migration is likely greater than the number of fish captured in this study (i.e., >3,700) due to the occurrence of overflow events and the short trapping period. A similar study carried out within the same system in the year 2000 captured approximately 20,000 smolts during the peak spring migration (Aarestrup et al., 2002), providing evidence to suggest that autumn migration is not trivial (approximately $20 \%$ of spring migration numbers), and is likely more significant than first thought. The mean length of smolts in 2000 was similar to the length of the autumn-migrating trout captured in the present study (approx. $14 \mathrm{~cm}, \mathrm{~K}$. Aarestrup, personal communication). Downstream migration of juveniles has been directly observed in other rivers such as the Imsa River, Norway (Jonsson \& Jonsson, 2002). A recent telemetry study by Winter et al. (2016) showed that autumn downstream migration of juvenile brown trout was evident in the Villestrup and Deerness streams of Denmark and England respectively. The evidence for autumn migration in S. trutta is growing and may have significant consequences on both stream and sea population dynamics (Winter et al., 2016), with important implications for management.

Autumn migrants may vary considerably from their spring counterparts in terms of their biology. For example, autumn migrants likely have lower gill sodium-potassium ATPase activity, as shown in juvenile Atlantic salmon (S. salar; Riley, Ibbotson, \& Beaumont, 2009). However, we found that both the size range and the sex ratio were similar to that previously reported for spring smolts (Jonsson, 1985). 


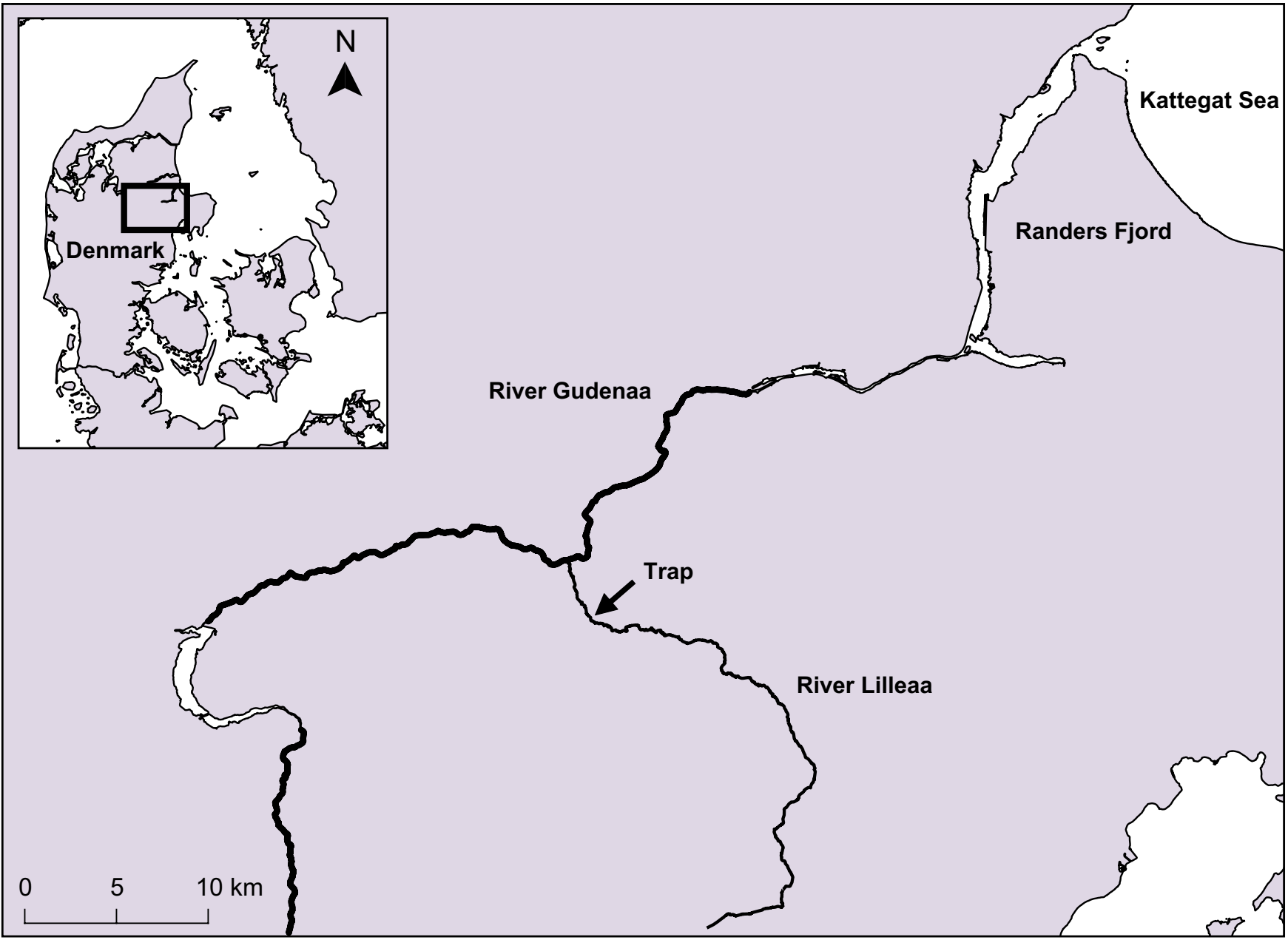

FIGURE 1 Map of the Lilleaa tributary and River Gudenaa with trap location

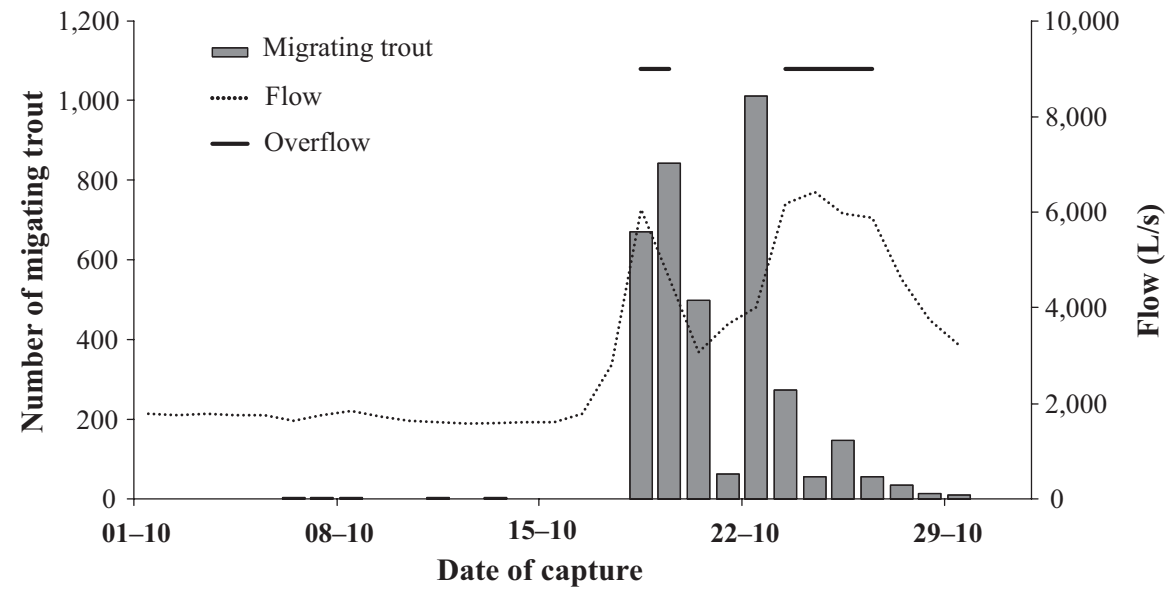

FIGURE 2 Daily records of migrating trout during October 2004. The number of juvenile brown trout (Salmo trutta) captured daily during trap operation $(n=3679)$ accompanied by water flow. Opening of the water gate to allow excess water flow is represented by the thick black line

In many ways, autumn migration resembles spring migration in River Lilleaa, suggesting that the movement of trout observed in autumn may be a presmolt migration and not just in-stream movements. The observed migrants with lengths ranging between 9 and $12 \mathrm{~cm}$ most likely contain both $0+$ and $1+$ fish, although we cannot draw that conclusion for certain given that we have no scales to confirm their age. Such individuals may in fact have reached the average smolt size had they migrated the following spring. Consequently, we cannot exclude the possibility that population density may urge individuals to migrate sooner due to competition for proper habitat and food resources. Furthermore, we cannot exclude the possibility that this phenomenon only occurs in rivers exiting in low salinity areas.

The environmental and physiological factors that contribute to these migratory tactics are still poorly understood. Our study does 




FIGURE 3 Length $(n=222)$ and sex $(n=84)$ distribution of a subsample of juvenile brown trout (Salmo trutta) captured on 18 October 2004

not provide information on the final destination of the migrating trout, perhaps the Randers Fjord and Kattegat Sea, or somewhere between the trap and the sea. However, the habitat in this stretch is considered unfavourable for trout with its depth $(\sim 2 \mathrm{~m})$, width $(\sim 30 \mathrm{~m})$ and presence of larger predatory fish such as pike (Esox lucius), suggesting that at least some of the trout detected at the trap migrated to sea although we cannot draw that conclusion for certain.

To this day, our knowledge of the movement ecology of salmonids remains incomplete (Dolinsek, McLaughlin, Grant, O'Connor, \& Pratt, 2014), and may impact the effectiveness of management strategies currently in place which often relies on downstream fish passage data. Conservation decision-making processes also rely on population measurements and survival estimates (Mace et al., 2008). Failure to consider autumn migration in migration estimates may result in significant population and juvenile to adult survival underestimates and thus have important conservation and management consequences (e.g., when regulating fish passage opening periods and spillway release at weirs and dams). The occurrence of autumn migration may also affect age determination using scales which relies on the width of growth rings to estimate time spent at sea and assumes that the first time fish enter marine waters is in the spring (Bagenal, 1974), which may affect estimates of population and age dynamics. We urge the development of more telemetry studies to evaluate the extent of this autumn migration, as it may have important consequences on salmonid management in streams of many regions of Europe. We further emphasise the need to consider this autumn-migratory phenotype as part of the salmonid paradigm (Gowan et al., 1994), as it may play an adaptive role in salmonid life-history strategies due to changing environmental conditions.

\section{ACKNOWLEDGEMENTS}

This study was funded by the Danish rod and net fish licence funds.

$$
\begin{array}{r}
\text { Kim Aarestrup }{ }^{1} \\
\text { Kim Birnie-Gauvin }^{1} \\
\text { Martin H. Larsen }^{1,2}
\end{array}
$$

${ }^{1}$ DTU AQUA, National Institute of Aquatic Resources, Section for Freshwater Fisheries Ecology, Technical University of Denmark, Silkeborg,

Denmark

${ }^{2}$ Danish Centre for Wild Salmon, Brusgårdsvej 15, DK-8960 Randers S $\varnothing$,

Denmark

Correspondence

Kim Aarestrup, DTU AQUA, National Institute of Aquatic Resources, Section for Freshwater Fisheries Ecology, Technical University of Denmark, Silkeborg, Denmark.

Email:kaa@aqua.dtu.dk

\section{REFERENCES}

Aarestrup, K., Nielsen, C., \& Koed, A. (2002). Net ground speed of downstream migrating radio-tagged Atlantic salmon (Salmo salar L.) and brown trout (Salmo trutta L.) smolts in relation to environmental factors. Hydrobiologia, 483, 95-102.

Bagenal, T. B. 1974. The ageing of fish: The proceedings of an international symposium. Old Woking, Surrey, UK: Unwin Brothers Ltd.

Cucherousset, J., Ombredane, D., Charles, K., Marchand, F., \& Baglinière, J.-L. (2005). A continuum of life history tactic in a brown trout (Salmo trutta) population. Canadian Journal of Fisheries and Aquatic Sciences, 62, $1600-1610$. 
Cunjak, R. A., Chadwick, E. M. P., \& Shears, M. (1989). Downstream movements and estuarine residence by Atlantic salmon parr (Salmo salar). Canadian Journal of Fisheries and Aquatic Sciences, 46, 1466-1471.

Davidsen, J. G., Rikardsen, A. H., Thorstad, E. B., Halttunen, E., Mitamura, H., Præbel, K., ... Næsje, T. F. (2013). Homing behaviour of Atlantic salmon (Salmo salar) during final phase of marine migration and river entry. Canadian Journal of Fisheries and Aquatic Sciences, 70, 794-802.

Dolinsek, I. J., McLaughlin, R. L., Grant, J. W., O'Connor, L. M., \& Pratt, T. C. (2014). Do natural history data predict the movement ecology of fishes in Lake Ontario streams? Canadian Journal of Fisheries and Aquatic Sciences, 71, 1171-1185.

Gowan, C., Young, M. K., Fausch, K. D., \& Riley, S. C. (1994). Restricted movement in resident stream salmonids: A paradigm lost? Canadian Journal of Fisheries and Aquatic Sciences, 51, 2626-2637.

Jonsson, B. (1985). Life-history patterns of freshwater resident and sea-run migrant brown trout in Norway. Transactions of the American Fisheries Society, 114, 182-194.

Jonsson, B., \& Jonsson, N. (1993). Partial migration: Niche shift versus sexual maturation in fishes. Reviews in Fish Biology and Fisheries, 3, 348-365.

Jonsson, N., \& Jonsson, B. (2002). Migration of anadromous brown trout Salmo trutta in a Norwegian river. Freshwater Biology, 47, 1391-1401.
Jonsson, B., \& Jonsson, N. (2014). Time and size at seaward migration influence the sea survival of Atlantic salmon (Salmo salar L.). Journal of Fish Biology, 84, 1457-1473.

Klemetsen, A., Amundsen, P. A., Dempson, J. B., Jonsson, B., Jonsson, N., Oconnell, M. F., \& Mortensen, E. (2003). Atlantic salmon Salmo salar L., brown trout Salmo trutta L. and Arctic charr Salvelinus alpinus L.: A review of aspects of their life histories. Ecology of Freshwater Fish, 12, 1-59.

Mace, G. M., Collar, N. J., Gaston, K. J., Hilton-Taylor, C., Akçakaya, H. R., Leader-Williams, N., ... Stuart, S. N. (2008). Quantification of extinction risk: IUCN's system for classifying threatened species. Conservation Biology, 22, 1424-1442.

R Core Team. (2013). R: a language and environment for statistical computing. R Foundation for Statistical Computing, Vienna, Austria.

Riley, W. D., Ibbotson, A. T., \& Beaumont, W. R. C. (2009). Adult returns from Atlantic salmon, Salmo salar, parr autumn migrants. Fisheries Management and Ecology, 16, 75-76.

Winter, E. R., Tummers, J. S., Aarestrup, K., Baktoft, H., \& Lucas, M. C. (2016). Investigating the phenology of seaward migration of juvenile brown trout (Salmo trutta) in two European populations. Hydrobiologia, 775, 139-151. 